\section{How Thought Presents Itself among the Phenomena of Nature}

In your paper of the 5th you give a short abstract of a recent lecture at the Royal Institution by Mr. G. Johnstone Stoney, on the question "How Thought presents itself among the Phenomena of Nature." In this abstract I observe an assertion which is quite new to me, and, I must add, quite unintelligible. It occurs in the first paragraph. The assertion seems to be that there is an absolute distinction between molar and molecular motion, inasmuch as that, in the case of molecular motion therc is no authority for the conviction that there must be some "thing" to be moved. The conception of motion involves the conception of matter as a necessary or inseparable concomitantalthough the abstract idea of motion may, in a sense, be separately entertained. Is there any difference in this respect between molar and molecular motion? A molecule is a group of atoms, and an atom is only conceivable as an ultimate particle of matter. I hope that some further explanation may be given upon this point, which is one of the highest interest and importancc, both as a matter of physical and of metaphysical speculation.

Inverary, March 8

Akgyet.

\section{The Compound Vision and Morphology of the Eye in Insects}

MR. SYDNEY Hickson, in your issue of February $\mathbf{I} 2$ (p. 34 $\mathbf{r}$ ), makes certain statements concerning my paper in the Trans. actions of the Linnean Society on this subject. I will not follow Mr. Hickson through his entire article, as I conceive it is suffciently refuted by my paper itself. He says: "It would be tedious to bring evidence of this kind to confirm a theory which is already fully established." I would ask Mr. Hickson if any. one can explain the vision of the compound eye intelligibly on the received theory? I would also remind your readers that Prof. Huxley, writing of the crayfish in 1880 , accepted the view with extreme caution; he said, "The exact mode of connection of the nerve fibres with the visual rods is not certainly made out ;" that Claparède never accepted it, and Max Schultze admitted that there were grave physical difficulties in the way of its acceptance.

Mr. Hickson is very anxious, apparently, to deny me what I never claimed-i.e. the discovery of a layer of definitc structure beneath the basilar membrane. What I do c'aim is the discovery of the nature of its elements. I deny, in my paper, that the optic nerve passes through these structures, and I deny that these consist of a fine reticulum of nerve-fibres. These are questions of fact and observation, not of theory or deduction. If I am wrong, I am wrong. But the way to test my work is by working out the eye as I have worked it out. I have spent nearly ten years in this work, and I do not expect to have my views generally accepted for another ten years.

The absence of pigment and retinal purple is a secondary question. I do not know, nor does any one know, whether there be retinal purple or not in this layer. I admit that pigment is absent in the retina (my retina) of some insects and crustaceans, and I have recorded the fact. I am not yet convinced that we can say vision is impossible without it. Albinos have vision undoubtedly in the absence of retinal pigment. He would be a bold man who asserted that vision could not be effected without pigment in the retinal region. 'The colourless collodion film of the photographer is affected; why not retinal rods? Here, again, it is a question of fact, not theory.

The presence of pigment proves nothing with regard to the function of the great ruds, any more than it shows that the iris of a vertebrate is sensitive to light.

The absence of my retinal layer in Periplaneta and Nepa is imaginary on the part of my critic, for I have examined it carefully in both, and I figure the elements from the former. I maintain that the same structures exist in all the crustacea, although they are short and more difficult to demonstrate.

Again, in the morphological yuestion my views are not fairly stated by Mr. Hickson. I admit his facts, bul deny his deductions. The hypodermis forms the dioptric structures, as the epidermis of the vertebrate forms the lens; my contention is that the retina in the insect, like the same structure in the Vertebrata, is developed as an outgrowth from the nervons system.

BenJamin THOMPSON LOWNe

65, Cambridge Gardens, Notting Hill, W., February 23
I Do not wish to undertake a lengthy controversy with $\mathrm{Mr}$. Lowne on the question of the retina of insects, but I cannot refrain from making a few remarks on the letter you publish above.

I am afraid Mr. Lowne has misunderstood my criticism when he asks me "If any one can explain the vision of the compound eye intelligibly on the reccived theory?" My criticism was not meant for any theory of pure optics, but for the theory that the retinula are not the true nerve-end cells.

Mr. Lowne's statement that albinos are devoid of retinal pigment is not strictly accurate, for Kühne pointed out, and any one can see for himself, that all albino rabbits and other vertebrates possess a true retina purple. Moreover, the rods of Cephalopods and of Pecten, which secm to be devoid of pigment in spirit specimens, possess, as Hensen has pointed out, a true retina purple. In fact, I know of no exception to the rule I laid down-namely, that optic nerve-end cells are pigmented, and I should be glad if any of your readers could point out any exceptions to it.

Mr. Lowne's reiterated statement that the optic nerve fibrils do not end in the retinulæe is, as I said, contrary to my own observations, I have submitted my preparations to several eminent naturalists, who agree with me in my account of their distribution. I shall be happy to submit them to any others who may feel interested in this matter.

The other statements in my notice which Mr. Lowne controverts I will not refer to again here, as they will be fully explained and illustrated in my forthcoming paper in the Quarterly Fournal of Microscopical Science, the proof-sheets of which I have now in hand. SydNEY J. IHickson

Anatomical Department, Museum, Oxford, February 25

\section{Civilisation and Eyesight}

In connection with Lord Rayleigh's letter in NATURE, p. 340 , on the above subject, I venture to hope that the following may be of interest :-

In the "Expression of the Emotions" the late Mr. Darwin quotes some observations-if I recollect correctly-by Gratiolet tending to show that, under the influence of fear, the pupils of animals' eyes dilate. Observations extending over some years have convinced me that fear is undoubtedly capable of thus causing dilation of the pupils (see Dr. Hack Tuke, "Influence of the Mind on the Body") ; and in general literature, such as travels, novels, \&c., I have met with many instances in which the cyes of both men and animals under this condition have been so described by the writers.

Is dilation of the pupil under the influcnce of fear to be explained on the assumption that the increased aperture of the eye enables a more effective scrutiny of the object causing terror, and has thus been of service in the struggle for existence?

An answer to this question is not easy to give, for, although dilation of the pupil under the influence of fear may have originally been of direct service to an animal, yet this condition may in time have come to be associated with other emotions in which it is not so easy to trace any such direct benefit.

Observations upon the subject are by no means easy (varying light, for instance, varies the aperture of the eyc), but in the course of my observations I became much inclined to believe that other strong mental emotions besides fear $\langle e, g .$, , joy or pleasure) may be capable of giving rise to dilated pupils.

Charlotte Hrontè, in "Jane Eyre," is one of the only writers who associates a dilated pupil with other emotions than fear. Here is the sentence :- "Yain, shame, ire, impatience, disgust, detestation, seemed momentarily to hold a quivering conflict in the larse pupil dilating under his ebon brow."

It is to be feared that the experimental investigation of eyesight with artificially contracted or dilated pupils is scarcely practicable, for drugs, such as atropine or eserine, act not only on the pupil, but also on the power of accommodation for distance.

Liverpool, February $2 \mathbf{I}$

P.S.-I see Dr. M. Fuster, in his "Text-Book of Physiology," mentions the dilation or contraction of the pupil which attends the adjustment of the eye for distant or near objects respectively, and also its dilation "as an effcct of emotions." It thus seems highly probable that strong and very different montal emotions may give rise to dilated pupil. Dr. Herdman has suggested to me, as an explanation of this, that an intens 